\title{
FREQUENCY OF SICKLE CELL ANAEMIA AND SICKLE CELL TRAIT IN PATIENTS REFERRED TO HEGLIG HOSPITAL IN WESTERN KORDOFAN STATE (SUDAN)
}

\author{
Osama Atiat Alla Babiker Ahmed ${ }^{1}$, Malik Hassan Ibrahim Elfadni²
}

${ }^{1}$ Lecturer, Department of Clinical Laboratory Sciences, College of Applied Medical Sciences, Shaqra University, Shaqra, Saudi Arabia 2Professor, Department of Clinical Laboratory Sciences, College of Graduate Studies, Sudan University of Science and Technology, Sudan.

\section{ABSTRACT}

\section{BACKGROUND}

Sickle cell anaemia is prevalent in several countries including Sudan. To create awareness among people, study of incidence of the disease is important.

\section{MATERIALS AND METHODS}

This study was a descriptive study conducted to determine the sickle cell disease and sickle cell trait frequency in Sudanese patients referred to Heglig hospital in Southern Kordofan state (Sudan) between November 2008 to February 2009. One hundred (100) patients participated in the study and informed consent was obtained from them. Venous blood was collected and investigated for sickle cell disease and sickle cell trait, a complete blood count (CBC), sickling test and haemoglobin electrophoresis were carried out. Fully automated haematological analyser (Sysmex Kx 21N), Electrophoresis tank and power pack were used for analysis and statistical package for social sciences (SPSS) computer program version 13 was used for data processing.

\section{RESULTS}

The results showed that percentage of sickle cell trait and sickle cell disease was $45 \%$ and $18 \%$ respectively. Haemoglobin level, total erythrocyte and packed cell volume of the sickle cell disease patients were (7.03), (2.68) and (22.52), respectively. There were no significant differences in individuals with sickle cell disease and normal individuals with regard to mean cell haemoglobin concentration, mean cell volume and mean cell haemoglobin respectively. The total leukocytes and platelets count were significantly elevated in sickle cell disease when compared with normal individuals.

\section{CONCLUSION}

Sickle cell anaemia is highly prevalent in the studied area which is most likely due to the consanguineous marriages.

\section{KEY WORDS}

Sickle Cell Anaemia, Sudan, Hereditary, Marriage.

HOW TO CITE THIS ARTICLE: Ahmed OAAB, Elfadni MHI. Frequency of sickle cell anaemia and sickle cell trait in patients referred to heglig hospital in Western Kordofan state (Sudan). J. Evolution Med. Dent. Sci. 2018;7(48):5212-5215, D0I: $10.14260 /$ jemds/2018/1156

\section{BACKGROUND}

Sickle cell disease is a major public health concern that has great impact on both individuals and society. Sickle cell disease is also associated with significant mortality. Sickle haemoglobin is a mutant haemoglobin in which valine is substituted for the glutamic acid normally at the sixth amino acid of the $\beta$-globin chain. This haemoglobin becomes polymerized and becomes poorly soluble when the oxygen tension is lowered and red cells that contain this haemoglobin become distorted and rigid. ${ }^{1}$ Sickle cell disease occurs when an individual is homozygous for the sickle cell mutation or is a compound heterozygote for sickle haemoglobin and $\beta$-thalassemia, haemoglobin $\mathrm{C}$, and some less common $\beta$-globin mutations. The disease is characterized by haemolytic anaemia and by three types of crises: painful (vasoocclusive), sequestration, and a plastic. ${ }^{2}$

'Financial or Other Competing Interest': None.

Submission 27-09-2018, Peer Review 11-11-2018,

Acceptance 17-11-2018, Published 26-11-2018.

Corresponding Author:

Osama Atiat Alla Babiker Ahmed,

College of Applied Medical Sciences,

Shaqra University,

Shaqra, Saudi Arabaia.

E-mail: oahmed@su.edu.sa

DOI: $10.14260 /$ jemds $/ 2018 / 1156$

\section{(c) $(1) \$$}

Sickle trait, the heterozygous state for sickle haemoglobin, affects approximately 8 percent of African-Americans and, with rare exceptions, is entirely benign. ${ }^{3}$

Sickle cell anaemia is one of the major problems in Sudan, especially in Western area where the gene frequency of this disease is quite prevalent. Most of the cases of sickle cell anaemia are detected after the patient reach the hospital with clinical symptoms. The spread of this disease is unfortunately the sickle traits who act as an instrumental for the propagation of this disease among the society through consanguineous marriages that, is traditionally favoured in Sudan especially in the Western Sudan. ${ }^{4}$

The Study aimed to detect the sickle cell trait patients in Heglig area to control the disease and create awareness among people of the genetic consequences of inbreeding and improve behaviour and attitude towards consanguineous marriages. The present study determines the full blood count, sickling test and haemoglobin electrophoresis in sickle cell disease and sickle cell trait in Heglig area and the morphological features of sickle cell trait and sickle cell disease.

\section{MATERIALS AND METHODS Study Design}

This descriptive study was conducted to determine the sickle cell trait frequency in patients referred to Heglig hospital in 
Western of Sothern Kordofan state between November 2008 to February 2009.

\section{Study Area}

The study was conducted in Heglig hospital because, it was central area with highly numbers of cases.

\section{Study Population}

Patients referred to Heglig hospital and belonging to Meseria tribe and those agreeing to participate in the study were investigated for sickle cell disease and sickle cell trait.

\section{Sampling}

The frame included all families of Meseria tribe who, have one member diagnosed as sickle cell disease and referred to Heglig hospital.

\section{Inclusion Criteria}

All families who have confirmed patient diagnosed as ( $\mathrm{Hb} \mathrm{S}$ disease) homozygosis patient.

\section{Exclusion Criteria}

All family who had no one diagnosed with sickle cell disease.

\section{Sample Size}

In view of the design of this study, the samples (cases) were selected by a simple random sampling method (probability sampling). The study sample size was set as hundred (100) patients.

\section{Tools of Data Collection}

The data was collected using laboratory investigations: CBC, sickling test and $\mathrm{HB}$ electrophoresis to detect haemoglobin $\mathrm{S}$. Also, interview was used to obtain age, sex and family history.

\section{Data Analysis}

The collected data was analysed to obtain the mean, standard deviation and frequencies using statistical package for social sciences (SPSS) computer program version 13.

\section{Ethical Consideration}

It was considered that all personal information that obtained from patients was kept confidential. The participants were provided with information about the study and any risk that may arise especially when the collection technique was applied, and their signed consent was obtained. In case of children, their parents gave consent for participation in the study.

\section{Method of Sample Collection}

A complete blood count (CBC), sickling test and $\mathrm{Hb}$ electrophoresis were carried out followed a simple procedure. Venous blood $(2.5 \mathrm{ml})$ was collected in ethylenediamine-tetra-acetic acid (EDTA) containers.

\section{Method of Automated Analyzer System (Complete Haemogram) \\ The blood sample was analysed by Sysmex Kx 21N (Sysmex Corporation; Mundelein, Illinois, Sysmex America, Inc.) fully automated haematological analyser. 5}

\section{Preparation and Staining of Blood Films}

Blood films were prepared from fresh blood with no anticoagulant added or from ethylene diamine tetra -acetic acid (EDTA) ant coagulated blood6. The films were fixed by absolute methanol and stained with Leishman's stain.

\section{Sickling Test}

Mixed 3 volumes of $\mathrm{Na}_{2} \mathrm{HPO}_{4}$ with 2 volumes of $\mathrm{Na}_{2} \mathrm{~S}_{2} \mathrm{O}_{4}$ to obtain $\mathrm{pH}$ of 6.8 in the resultant solution. Five 5 drops of the freshly prepared reagent were added to drop of anticoagulated blood on a slide, and cover glass were sealed together with a petroleum jelly/paraffin wax mixture or with nail varnish. Sickling takes place almost immediately in sickle cell anaemia. Sickle cell trait was observed within 1 hour. A test on positive control of $\mathrm{Hb} \mathrm{A}$ plus $\mathrm{Hb} \mathrm{S}$ were performed at the same time. 6

\section{Electrophoresis Method}

A horizontal electrophoresis tank that allowed a bridge gap of $7 \mathrm{~cm}$ was used. A direct current power supply capable of delivering $350 \mathrm{~V}$ at $50 \mathrm{~mA}$ was suitable for both cellulose acetate and citrate agar electrophoresis ${ }^{6}$, Samples were centrifuged at $1200 \mathrm{~g}$ for $5 \mathrm{~min}$. Then twenty (20) $\mu \mathrm{l}$ of the packed red cells was diluted with $150 \mu \mathrm{l}$ of the haemolyzing reagent, mixed gently and left for at least $5 \mathrm{~min}$, then the power supply was disconnected. The electrophoresis tank was prepared by placing equal amounts of TEB buffer in each of the outer buffer compartments. Wet two chamber wicks in the buffer, and placed one along each divider/bridge support ensuring that they make good contact with the buffer after that the cellulose acetate was soaked by lowering it slowly into a reservoir of buffer, the cellulose acetate was left to soak for at least $5 \mathrm{~min}$ before used, then the sample well plate was filled with $5 \mu \mathrm{l}$ of each diluted sample or control and was covered with a 50-mm cover slip or a "short" glass slide to prevent evaporation. a second sample well plate was loaded with Zip-prep solution, then the applicator tips immediately prior was cleaned to use by loading with Zip-prep solution and then applying them to a blotter, after that the cellulose acetate strip was removed from the buffer and blotted twice between two layers of clean blotting paper. The cellulose acetate was not allowed to dry, then the applicator was Loaded by depressing the tips into the sample wells twice and applied this first loading onto some clean blotting paper. the applicator was reloaded and applied the samples to the cellulose acetate. Then the cellulose acetate plates was placed across the bridges, with the plastic side uppermost. two glass slides were placed across the strip to maintain good contact. Electrophorese at $350 \mathrm{~V}$ for $25 \mathrm{~min}$, after $25 \mathrm{~min}$ electrophoresis, immediately the cellulose acetate was transferred to Ponceau $\mathrm{S}$ and fixed and stained for $5 \mathrm{~min}$, after that Excess stain was removed by washing for $5 \mathrm{~min}$ in the first acetic acid reservoir and for $10 \mathrm{~min}$ in each of the remaining two. Blotted once, using clean blotting paper, and left to dry, then the membranes were labelled and stored in a protective plastic envelope.

\section{Statistical Analysis}

Results are given as mean \pm S. E. M. The statistically significant difference was determined using one-way analysis of variance (ANOVA) followed by Tukey's test. The results were considered statistically different when $\mathrm{P}<0.05$. 


\section{RESULTS}

Study population were Meseria (100 participants), from Heglig area in Southern West of Kordofan. The gender frequency was $58 \%$ of females and the remaining were males $42 \%$. The mean of the study population age was 20.18 years. The haemoglobin level, total erythrocytes count $\left(10^{6} / \mu\right)$, mean cell haemoglobin concentration $(\mathrm{g} / \mathrm{dl})$, mean cell volume (fl), packed cell volume (\%), mean cell haemoglobin $(\mathrm{pg})$, total leukocytes count $\left(10^{3} / \mu \mathrm{l}\right)$ and platelet count $\left(10^{3} / \mu \mathrm{l}\right)$ of sickle cell disease is shown in Table 1

The full blood count among sickle cell disease patients was compared with that of the normal individuals as shown in table 2, the mean age of the sickle cell disease patients (10.32) was not significantly differed of that of normal individuals (haemoglobin AA) ( $p<0.138)$. The total erythrocytes was significantly decreased in sickle cell disease $(\mathrm{p}<0.001)$ when compared with normal and sickle cell trait, also the haemoglobin concentration and packed cell volume were significantly lower than that of normal individuals and sickle cell trait patients $(\mathrm{p}<0.001)(\mathrm{p}<0.001)$, respectively, indicated to anaemia in sickle cell disease patients. The total leukocytes count was significantly elevated in sickle cell disease when compared with normal individuals $(\mathrm{p}<0.001)$. The platelet count was significantly increased in sickle cell disease patients.

\begin{tabular}{|c|c|}
\hline The Parameters & Mean \pm SD \\
\hline The age & $20.1820 \pm 15.62313$ \\
\hline Total erythrocytes $\left(10^{6} / \mu \mathrm{l}\right)$ & $4.1159 \pm 1.05085$ \\
\hline Haemoglobin $(\mathrm{g} / \mathrm{dl})$ & $11.0240 \pm 2.94564$ \\
\hline $\begin{array}{l}\text { Mean cell haemoglobin } \\
\text { concentration } \mathrm{g} / \mathrm{dl}\end{array}$ & $31.9010 \pm 2.17940$ \\
\hline Mean cell volume (MCV) fl & $84.0280 \pm 7.70221$ \\
\hline Packed cell volume \% & $34.2770 \pm 8.22250$ \\
\hline Mean cell haemoglobin pg & $26.9790 \pm 3.42652$ \\
\hline The total leukocytes $\left(10^{3} / \mu \mathrm{l}\right)$ & $8.8910 \pm 5.63745$ \\
\hline Platelet count $\left(10^{3} / \mu \mathrm{l}\right)$ & $284.2600 \pm 131.47751$ \\
\hline \multicolumn{2}{|c|}{$\begin{array}{l}\text { Table 1. The Full Blood Count and Age for the Study } \\
\text { Population Group }\end{array}$} \\
\hline
\end{tabular}

All values are mean $\pm S D, n=100$.

\begin{tabular}{|c|c|c|c|}
\hline \multirow{2}{*}{ The Parameters } & AS & SS & AA \\
\hline & \multicolumn{3}{|c|}{ Mean \pm SD } \\
\hline The age & $\begin{array}{l}28.1333 \pm \\
9.89^{* * *}\end{array}$ & $\begin{array}{l}10.3278 \pm \\
9.86\end{array}$ & $\begin{array}{l}15.3054 \pm \\
7.89\end{array}$ \\
\hline $\begin{array}{c}\text { Total erythrocytes } \\
\left(10^{6} / \mu \mathrm{l}\right)\end{array}$ & & $\begin{array}{l}2.6822 \pm \\
0.1410^{* * *}\end{array}$ & $\begin{array}{c}4.3305 \pm \\
0.5610\end{array}$ \\
\hline Haemoglobin (g/dl) & $\begin{array}{c}11.9400 \pm \\
0.9870\end{array}$ & $\begin{array}{l}7.0389 \pm \\
0.3650^{* * *}\end{array}$ & $\begin{array}{c}11.8486 \pm \\
0.6890\end{array}$ \\
\hline $\begin{array}{l}\text { Mean cell haemoglobin } \\
\text { concentration g/dl }\end{array}$ & $\begin{array}{c}32.1400 \pm \\
4.5691\end{array}$ & $\begin{array}{c}31.2000 \pm \\
6.9874\end{array}$ & $\begin{array}{c}31.9514 \pm \\
5.9713\end{array}$ \\
\hline $\begin{array}{l}\text { Mean cell volume } \\
\text { (MCV) fl }\end{array}$ & $\begin{array}{c}82.3000 \pm \\
10.6988\end{array}$ & $\begin{array}{c}86.8500 \pm \\
26.5143\end{array}$ & $\begin{array}{c}84.7568 \pm \\
36.1127\end{array}$ \\
\hline Packed cell volume $\%$ & $\begin{array}{c}36.9067 \pm \\
5.3591 \\
\end{array}$ & $\begin{array}{l}22.5278 \pm \\
4.3651^{* * *} \\
\end{array}$ & $\begin{array}{c}36.7946 \pm \\
5.4563\end{array}$ \\
\hline $\begin{array}{r}\text { Mean cell haen } \\
(\mathrm{MCH})\end{array}$ & $\begin{array}{c}26.4867 \pm \\
4.5980 \\
\end{array}$ & $\begin{array}{c}27.1667 \pm \\
6.3591 \\
\end{array}$ & $\begin{array}{c}27.4865 \pm \\
3.2147 \\
\end{array}$ \\
\hline $\begin{array}{r}\text { The total } \\
(10\end{array}$ & $\begin{array}{c}7.0333 \pm \\
1.2365\end{array}$ & $\begin{array}{l}15.5333 \pm \\
2.5691^{* * *}\end{array}$ & $\begin{array}{c}7.9189 \pm 3.6 \\
981\end{array}$ \\
\hline $\begin{array}{c}\text { Platelet count } \\
\left(10^{3} / \mu \mathrm{l}\right)\end{array}$ & $\begin{array}{c}245.4667 \pm \\
67.1260 \\
\end{array}$ & $\begin{array}{l}393.0556 \pm \\
62.5698^{* *}\end{array}$ & \begin{tabular}{|c|}
$278.5135 \pm$ \\
69.1254
\end{tabular} \\
\hline & & & AA), Sickle \\
\hline
\end{tabular}

All values are mean $\pm \mathrm{SD},{ }^{* * *} \mathrm{P}<0.001$ compared to $\mathrm{AA}$, $n=43$ for $A S, n=18$ for $S S$ and $n=37$ for $A A$.

\section{DISCUSSION}

This study was done to investigate and detect the sickle cell disease and sickle cell trait among Meseria patients referred to Heglig hospital in Southern West of Kordofan. One hundred (100) individuals of Meseria were investigated for full blood count, sickling test and haemoglobin electrophoresis. As shown, the study population comprised 42 males and 58 females. The results showed that frequency of sickle cell trait and sickle cell disease were (45\%) and (18\%) respectively.

The total erythrocytes was significantly decreased in sickle cell disease when compared with normal and sickle cell trait, also the haemoglobin concentration and packed cell volume were significantly lower than that of normal individuals and sickle cell trait patients, respectively, indicated to anaemia in sickle cell disease patients, this results agreed with Losek et al, ${ }^{7}$ whom observed anaemia significantly more often in patients with sickle cell disease compared with sickle cell trait at all ages 3 months and older.

Total and segmented leukocyte numbers were greatly increased during vasoocclusive crisis and infection, but only with bacterial infection was there a consistent increase in bands or non-segmented leukocytes (mean, 4, 580/ $\mu$ l). On the basis of these data we believe that total and differential leukocyte counts are of value for identifying those children with potentially serious bacterial infections. ${ }^{8}$

Despite a clear role for leukocytes in modulating the pathophysiology of sickle cell disease (SCD), the mechanism by which leukocyte numbers are increased in this disorder remains unclear. Hypothesizing that the chronic inflammatory state, elicited by adhesive interactions involving various cell types, might underlie leukocytosis. ${ }^{9}$ The platelet count was significantly increased in sickle cell disease patients. There is increasing evidence suggesting the contribution of platelets in the vasoocclusive phenomena found in sickle cell anaemia. ${ }^{10}$

The characteristics of $\mathrm{Hb}$ SS disease observed in this study did not differ significantly from those of other series studied elsewhere, the haematological indices and clinical manifestations of sickle cell disease (SCD) patients in Nigeria were detected by Nduka et al, 11 whom they were investigated in a combined group of male and female Nigerians, and the results were matched against those from non-SCD individuals. Haemoglobin concentrations $(\mathrm{Hb})$, red blood cell count (RBC) and packed cell volume (PCV) were significantly lower in the haemoglobin SS (Hb SS) individuals than in the haemoglobin AS ( $\mathrm{Hb}$ AS) and haemoglobin AA ( $\mathrm{Hb}$ AA) individuals. White cell count (WBC) was of course higher in the $\mathrm{Hb}$ SS patients. This study was compared with other studies done in Arab world, as in Bahrain, Buhazza et al.12 Found that most of the parents of the sickle cell disease in Bahrain were consanguineous. Al Arrayed and Haites ${ }^{13}$ also determined the haematological characteristics of Bahraini sickle cell disease patients. Most of the patients had low haemoglobin levels, low HCT, low MCH, and low MCV (Microcytosis) levels. The later was thought to be due to the co-existence of alpha-thalassemia gene. White et al. 14 Analysed 5000 subjects from three major Peninsular Arab States and determined the frequency of sickle cell disease in Yemen to be $0.95 \%$. 
In Sudan, the incidence of abnormal haemoglobin among five indigenous and two immigrant groups studied. The indigenous groups were consisting of Nubians (Northern Sudan), Kalakla (Central), Dinka (Southern), Ingassena (South Eastern), and Beja (Eastern). The two immigrant groups were Nigerians (Western bank of the Blue Nile) and Tchiendians (Central Sudan). Blood samples were collected from about 100 unrelated males of each tribe, except for Tchiendians in which the collected samples were only 54 samples. Sickle cell test and haemoglobin paper electrophoresis were used to detect abnormal haemoglobin. The highest sickle cell trait incidence was found in the immigrant tribes, the Nigerians (27\%) and Tchiendians (20\%). Igassena tribe showed no evidence of abnormal haemoglobin and that tribe was thought to be a pure line of the original population of Sudan. Similarly, Beja tribe had no abnormal haemoglobin which could be referred to its close community. The incidence of abnormal haemoglobin in Dinka was about 8\% which was higher than the previously reported studies. Different results in Dinka were attributed to the test method variations. Kalakla displayed zero percent of abnormal haemoglobin, however, it is considered to be of mixed origin. ${ }^{15}$

The distribution of the $S$ gene among various ethnic and linguistic groups in the Sudan studied; they found that, the majority of patients (93.7\%) belonged to families of single ethnic descent, indicating the high degree of within-group marriages and thus the higher risk of augmenting the gene. SCA was found to be predominant among the Afro-Asiaticspeaking groups (68.4\%) including nomadic groups of Arab and non- Arab descent that migrated to the Sudan in various historical epochs. Those patients clustered in western Sudan (Kordofan and Darfur) from where $73 \%$ of all cases originate. The proportion of patients reporting from other geographic areas like the south (3.1\%), which is primarily inhabited by Nilo-Saharan-speaking groups (19\% of the whole sample) who populated the country in previous times, is disproportionate to their total population in the country. ${ }^{16}$ Also, 84\% of sickle cell disease patients Estimated were from the Baggara tribe in Western Sudan. ${ }^{17}$

\section{CONCLUSION}

This study investigated the frequency of sickle cell trait and sickle cell disease among Meseria tribe and compared the haematological characteristics of both against normal individuals. The study concluded that the frequency of sickle cell trait was high in Meseria tribe, also the frequency of sickle cell disease was high. Erythrocyte count, haemoglobin concentration and packed cell volume were low in Sudanese sickle cell disease patients and the total leukocytes and platelets count were elevated in Sudanese sickle cell disease patients.

\section{REFERENCES}

[1] Rees DC, Williams TN, Gladwin MT. Sickle-cell disease. Lancet 2010;376(9757):2018-31.
[2] Naik RP, Haywood C Jr. Sickle cell trait diagnosis: clinical and social implications. Hematology Am Soc Hematol Educ Program 2015;2015:160-7.

[3] Bello-Manga H, DeBaun MR, Kassim AA. Epidemiology and treatment of relative anaemia in children with sickle cell disease in sub-Saharan Africa. Expert Rev Hematol 2016;9(11):1031-42.

[4] Sabahelzain MM, Hamamy H. The ethnic distribution of sickle cell disease in Sudan. Pan Afr Med J 2014;18:13.

[5] Barbara BJ. Blood cells a practical guide. $4^{\text {th }}$ edn. Oxford, UK: Blackwell Publishing Ltd., 2006.

[6] Lewis MS, Bain BJ, Bates I. Practical haematology. 10 th edn. Philadelphia, United States of America: Elsevier Ltd., 2006.

[7] Losek JD, Hellmich TR, Hoffman GM. Diagnostic value of anaemia, red blood cell morphology and reticulocyte count for sickle cell disease. Ann Emerg Med 1992;21(8):915-8.

[8] Buchanan GR, Glader BE. Leukocyte counts in children with sickle cell disease. Comparative values in the steady state, vaso-occlusive crisis and bacterial infection. Am J Dis Child 1978;132(4):396-8.

[9] Conran N, Saad ST, Costa FF, et al. Leukocyte numbers correlate with plasma levels of granulocytemacrophage colony-stimulating factor in sickle cell disease. Ann Hematol 2007;86(4):255-61.

[10] Ibanga IA. Significance of platelet activation in sickle cell anaemia. Niger J Med 2006;15(2):148-50.

[11] Nduka N, Owhochuku SM, Odike P. Current observations on sickle cell genotype in Nigeria. East African Medical Journal 1993;70(10):646-9.

[12] Buhazza MA, Bikhazi AB, Khouri FP. Evaluation of haematological findings in 50 Bahraini patients with sickle cell disease and in some of their parents. J Med Genet 1985;22(4):293-5.

[13] Al Arrayed SS, Haites N. Features of sickle-cell disease in Bahrain. East Mediterr Health J 1995;1(1):112-9.

[14] White JM, Byrne M, Richards R, et al. Red cell genetic abnormalities in Peninsular Arabs: sickle haemoglobin, G6PD deficiency and alpha and beta Thalassaemia. J Med Genet 1986;23(3):245-51.

[15] Omer A, Ali M, Omer AH, et al. Incidence of G-6-PD deficiency and abnormal haemoglobins in the indigenous and immigrant tribes of the Sudan. Trop Geogr Med 1972;24(4):401-5.

[16] Mohammed AO, Attalla B, Bashir FM, et al. Relationship of the sickle cell gene to the ethnic and geographic groups populating the Sudan. Community Genet 2006;9(2):113-20.

[17] Bayoumi RA, Abu Zeid YA, Sadig AA, et al. Sickle cell disease in Sudan. Transactions of the Royal Society of Tropical Medicine and Hygiene 1988;82(1):164-8. 